\title{
THE EVOLUTION OF THE ROMANIAN PASTRY. TRADITIONS, EUROPEAN INFLUENCES, NEW TRENDS
}

\author{
Adina Săcara-Oniţa ${ }^{1}$ \\ Andra-Teodora Porumb ${ }^{2}$ \\ Ciprian Beniamin Benea ${ }^{3}$
}

DOI: https://doi.org/10.31410/ITEMA.2019.35

\begin{abstract}
In the last 30 years, the food industry and especially the pastry industry has experienced a spectacular dynamic in the landscape of the Romanian economy. Few of the big companies in the communist period in the field of bakery managed to maintain and adapt to the new, most of them went bankrupt or divided into smaller departments. In the first years after the revolution, Romanian investors look to invest mainly in bakery units specialized in bread, sometimes in simple salt or sesame bagels, white or black bread rolls production. The pastry was not perceived as a profitable business, especially due to the lack of qualified personnel and the lack of ingredients. The communist leadership considered the pastry products to be luxury products, for which raw materials would have been needed, but these were mainly sent for export. In this paper we intend to show the recent evolution of the units in the bakery field, highlighting three major trends: restoring in the foreground the Romanian tradition from the interwar period with the reinterpretation of the classic recipes; taking over brands, concepts and products that have been successful in France, Italy and Germany and which are the emblem of a western lifestyle, with the rapid adoption in the confectionery and chocolate fields; adaptation to the influence of Hungarian and German gastronomic culture - especially in Transylvania. Last but not least, we will show that pastry is nowadays reluctant for customers, especially due to the use of sugar and margarine-type fats. The new trend is the introduction of butter in pastry following the French model, but this aspect involves high costs, these new products can only be purchased by certain social classes. In our opinion, genuine pastry will become a niche product.
\end{abstract}

Keywords: Bakery Field, Brand, Organizational Identity, Advertising Strategy, Web Site, Food Safety.

\section{INTRODUCTION}

$\mathrm{T}$ he bakery, and later the pastry, have had a spectacular evolution over the centuries. In this paper we intend to show how these sectors evolved in Romania, the influences that marked them, their current status and development prospects. These are extremely dynamic sectors, with over 5,000 producers, which in the last years have registered a turnover of about 2.5 billion Euro/ year.

\section{SHORT HISTORY OF PASTRY}

The pastry products were born from the handling of bread dough, being served at ceremonies and solemnities. In the Greek and Roman world, bakers have started to make cakes using eggs, wheat or oatmeal, milk, honey and wine, almonds, turmeric, figs, nuts and various types of

1 University of Oradea, Faculty of Economic Sciences, Department of International Business, 1 Universităţii Street, Oradea, 410087, Bihor, Romania

2 University of Oradea, Faculty of Economic Sciences, Department of International Business, 1 Universităţii Street, Oradea, 410087, Bihor, Romania

3 University of Oradea, Faculty of Economic Sciences, Department of International Business, 1 Universităţii Street, Oradea, 410087, Bihor, Romania 
cheese. In fact, it is said that the first cakes prepared were in the form of a pyramid and were brought by the Greeks as an offering to Dyonisos.

After $1000 \mathrm{AD}$, Arab merchants brought spices and citrus fruits to Europe. The bakers began to use more and more cinnamon, ginger, rice, sesame, cloves, nutmeg. In the thirteenth century, the Turks brought pastry products to Europe. Also, in the Middle Ages, the Crusaders bring sweet recipes to Europe, as well, which will be adapted by the chefs of the time.

At the end of the sixteenth century, with the discovery of the sugar cane, sugar begins to be used in the composition of the pastry products. Thus, the production of chocolate, battered dough, pastry and cream cakes develops, and the pastry business advances. The French import sponge cake, macarons or marzipan from Italy. Ice cream is also created in Italy, and in 1566 the guild of bakers appears. In Italy and France, the pie sheets are perfected. At the French royal court, pastry masters invented and cooked pastry products for the kings of France.

In 1645, yeast was invented and more and more types of dough were produced. In the 17 th century, the term ,dessert” appears, used to name the sweets served at the end of the meal. Cakes are baked, at the beginning of the next century, butter cakes, and at the beginning of the 19th century, egg and chocolate cakes.

It is said that the one who raised the pastry to the rank of art was Marie-Antoine (Antonin) Carême, the cook of Napoleon, of the King of England, George IV, or of the Tsar of Russia, Alexander. He also installs the toque that the bakers and cooks will wear.

At the end of the eighteenth century in Paris there were around 100 bakeries, and in France more than 40,000. While the pastry and confectionery products had previously been reserved exclusively for the nobility, with the industrial revolution more and more people had access to these products.

In the nineteenth century, in the European countries, pastries and confectioneries knew an unexpected success, even becoming meeting places for the bourgeoisie, cultural people and politicians of the time. The confectioners and pastry makers were educated in Paris, Vienna, Berlin, to then work in the capitals and big cities of the countries of origin and to develop their own recipes.

\section{THE PANIFICATION SECTOR IN ROMANIA}

Romanians have a true cult for bread, which is in close connection to beliefs, traditions and customs. Bread is generally used for holidays and events (weddings, baptisms, funerals). Ordinary people used to eat polenta, worked hard for earning their bread and never got to have sufficient bread until some decades ago. It was only at the end of the 19th century and at the beginning of the 20th century that bread and special bakery products (rolls, buns) were produced industrially, in the army's bakery units. These were the first high capacity production units, called ,manutanţe" (storehouses).

After the First World War, the first bakeries were created, and they used blenders and steam-heated ovens, the majority of which were "Dampf" type. Thus, the transition was made from manual kneading and from the earth oven, heated with wood, to the first modern devices, meant 
to increase both the quantity and the quality of the bread. In 1935, 36 mechanized bakeries functioned in Romania, with a number of 700 employees. Bread became a basic food product.

According to the data obtained by the daily newspaper Gândul from the National Institute of Statistics, a Romanian currently eats 546 grams of bakery and pastry products per day. This figure places Romania above the European average, according to the data of the last Eurobarometer, which shows that a European consumes 300 grams of bakery and pastry products.

ROMPAN President Aurel Popescu said that in 2018 in the milling and bakery industry, there were around 60,000 employees, with 10,000 less than in previous years, due to the massive migration of the Romanian population to other European countries and also due to the closing of vocational schools.

In Romania there still is a tradition of preparing bread in the house. From the market analysis conducted by the research company Gallup we find that $28 \%$ of the participants stated that they prepare bread and bakery products in their own homes, especially those in the rural area (39\% in the rural area and $19 \%$ in the urban area). The frequency is once or twice a week $(43 \%)$, once a month $(23 \%)$, once every $2-3$ months $(11 \%)$ and daily $(1 \%)$. More than half of them produce around $1-5 \mathrm{~kg}$ / month, $15 \%$ produce $6-10 \mathrm{~kg} /$ month, $9 \%$ below $1 \mathrm{~kg} /$ month. On average, people for whom bread baking is a hobby produce $7.6 \mathrm{~kg} /$ month. Bread is produced in homes, especially in the regions of Muntenia, Oltenia and Moldova (over $80 \%$ of the total quantity), followed by Crişana-Maramureş and Banat. The method of preparation is largely traditional (manual kneading and oven baking), only $4 \%$ of the respondents use household appliances. The reasons invoked would be the taste, the lower costs, the health, and having the ingredients from own crops.

Even if many imported bakery products and frozen bakery products have recently entered the Romanian market, being sold mainly in supermarkets, Romanians prefer local products. The main reason is their concern for health, and the frozen products contain many chemicals (E numbers, acidifiers and even bleaching agents).

Care for health is one of the premises that underlie the innovation attempts in the bakery field. If up to now the producers of bakery products aimed at optimizing quality at a low price, now it is intended to reap benefits in terms of nutrition, taste and health. Almost all companies, and especially the new ones, try to offer new products, using natural spices instead of chemicals. Researchers in the bakery field (Teodorescu, Toma, Pistol, 2019) claim that many spices (pepper, bay leaf, cloves, cinnamon, rosemary) have a therapeutic and nutritional potential thanks to the antimicrobial, antioxidant and anti-inflammatory effect, as well as technological potential since they work as true natural preservatives. However, they are also used in the pharmaceutical industry, being part of many herbal remedies.

\section{THE PASTRY SECTOR IN ROMANIA}

In Romania, the transition from bakery to pastry takes place in the eighteenth century, when chefs are beginning to be concerned with the creation of sweet products, to be served at the end of the nobles' meals. The oldest cookbook in Romanian Country dates from the 18th century. It was written during Constantin Brancoveanu's reign and included bread and dessert recipes. In the capital, in the eighteenth century, there were already places where food and desserts could be served. The most famous location in Bucharest where pastry and confectionery products 
could be served is „Capşa” (located on Calea Victoriei). It had a restaurant, a cafe, a confectionery and a hotel, it was frequented by the capital's elite, famous artists and politicians and became the supplier of the Romanian, Serbian and Bulgarian royal houses. It is said that Emperor Franz Josef, Tsar Alexander II, Kaisers Wilhelm I and II, former French President Raimond Poincaré or Greek Prime Minister Eleftherios Venizelos tasted the products prepared here by Emil Frederic, a confectionery chef taught in Paris and who regularly brought samples of the latest products made in Paris. Capşa was located on a place where in the seventeenth century there used to be the home of a great Romanian boyar. In 1830 the house was bought by the former cook of the ruler Grigorie IV Ghica, an Italian who opened an Italian-Oriental restaurant and a ballroom. Then the house was taken over by the Capsa brothers. One of them learned the job at the „Boisier House” in France. The success of Capşa House has led to the increase of the number of confectioneries and the emergence of several candy and chocolate factories.

Bucharest has been nicknamed, since the 19th century, the city of confectioners. There were then about 15 confectioners. The most successful were the confectioners of Venice, Germany and Turkey, which mainly served ice cream and sherbet. The best rated were the confectionery of some Italians („Giovanni” and „Comorelli”) and a French confectionery („Elefterescu”), where fine cakes were served.

During the interwar period, the number of confectioners and cafés increased significantly. The pastry chefs, who had attended schools already famous in France and Italy, proposed reinterpreted products and own creations, prepared with local ingredients. They had their own recipe book, with specialties that were only available in their stores, handwritten recipe books handed down to the disciples. In order to open a pastry shop or a confectionery one had to have attended a school and obtained a qualification.

After nationalization (1940-1950), all these units get into the state's ownership, more specifically that of the „Cooperativa”, and the patrons and pastry masters become mere employees.

During the communist era, the state factories in the field of bakery were organized at national level and centralized. Particular emphasis was placed on the production of bread, less white, blacker. The main products were: white, black and bran rolls, sugar buns, cocoa buns, „brânzoici" (sweet cheese rolls), and buns with different fruit fillings. The pastry products were sold through their own network of shops along with the bakery products.

The pastry products were seen as luxury products, accessible only to political activists or could be obtained very difficultly, through interventions, in the last period before the revolution. A plus of that period was the lack of harmful additives from the post-December period. The quantity produced was not big, the raw material was sent for export to pay off the external debt, but good quality raw material was processed. The creams were processed from local fruits, they were made from milk and eggs, and so was the dough.

The equipment of these production units was rudimentary because the Ceausescu regime did not want to invest in state-of-the-art foreign machinery, and the labour was cheap. With the revolution, the centralized structure of the food area collapsed. The old management was changed, the commercial relations with the raw material suppliers were stopped. The production units were grouped into smaller units, some of them continued their initial activity, others were destroyed, abandoned. The mammoth units could not adapt to the challenges of the market econ- 
omy. Foreign investors, through different investment funds, have purchased and refurbished some production units (Titan, Vel Pitar, Băneasa). The production units were relocated to the outskirts of the big cities or in the surrounding areas, leaving room for commercial spaces, offices or dwellings. The commercial spaces, i.e. the former bakery and pastry shops located in the central areas, were rented or sold, getting into the hands of real estate opportunists, conclusive examples being those of Titan factory in Bucharest or Pamora factory in Oradea.

In the first years after the revolution, Titan, Vel Pitar and Baneasa were the most important companies in the field of bakery and pastry in Romania. They made large-scale bakery products, but also „cozonac” (sweet bread), pasca (Easter cheesecake), sweet cheese rolls, buns, small sweet rolls, crackers, salty pastries, pretzels, pies, which they first sold in their own stores, and then through supermarket networks. Romanians are big consumers of cozonac (traditional dessert, preferred by over $80 \%$ of Romanians according to ROMPAN statistics - Romanian Patronage of the Milling, Bakery and Floury Products Industry), Easter cheesecake (the star of the Easter celebrations), crackers, salty pastries, pretzels, which they sell even nowadays, especially during holidays and events (weddings, baptisms, funerals).

After they had known success, companies such as Ana Pan (pastry company founded in 1990) and Dobrogea Group (first a milling and bakery company, created in 1961, then a bakery and pastry factory) introduced on the Romanian market the franchise with pastry products. In fact, the public is increasingly focusing on quality products and brands.

Last but not least, famous companies in the 1900s are reopened by the descendants of the founders. For example, the PETRU Bakery-Simigeria, founded in the capital in 1937, reopened after the Revolution, out of the desire of the descendants of the baker named PETRU to revive the traditions and recipes forgotten during the communist era. Today there is a PETRU store in almost all the big cities of the country, where, in addition to the famous sweet and salty savory specialties, they sell pizza, sandwiches and drinks.

Also, famous companies from abroad, for example PAUL bakery (founded in 1889 in Lille - France) and who had gained success due to concepts such as opening the workspace to let customers see how the products are baked, have opened franchises worldwide. The refinement and the quality of the products of this brand have conquered the Romanian profile market. The brand, which entered the Romanian market in 2008, also has a catering service, delivering products to companies and private clients and even organizing candy bars for events, parties and anniversaries. Another large company, Fornetti, of Hungarian origin, has opened numerous sale points in Romania, especially in the Transylvania region. It offers frozen specialties, with a constant quality that meets food safety standards (IFS Food and FSSC 22000 system). The products are baked on site and served hot to customers. The Fornetti franchise system makes it possible to obtain profits with small investments and minimal risks.

The Morarita brand offers specialties and frozen dough for pies and pastries especially through the supermarket network. It is a facility for customers who want to save time and have hot pastry specialties in their own home. The disadvantage is that margarine, vegetable oils and artificial preservatives are among the ingredients of these products.

Another competitor for traditional pastries is Bella, a brand present in Romania for the last 9 years, which sells frozen specialties: dough, pies, patisserie, strudels. Frozen pastry is increas- 
ingly successful because it offers comfort, longer shelf life and affordable prices. Persistence Market Research estimates that the frozen pastry segment on the European market will reach, by $2024,62.3 \%$ of the global market in the field. In Romania, the market and the consumption of frozen foods are among the lowest in Europe, having approximately 5\% of the bread market, but this segment has a steady growth rate.

The latest trend on the Romanian and European market is the shift from pastry to restaurant. Panemar brand, founded in 1993 in Cluj county, has succeeded in expanding its recipe for success in neighbouring counties. Under the slogan „Bread with soul”, the company first produced bread and sweet bread with traditional recipes, taking care to comply with international standards in food safety, quality management and environmental management (ISO 22000, ISO 9001, ISO 14001). Then they offered to the Romanian customers, in addition to the traditional apple or cheese pies, international pastry specialties (muffins, Bavarian pretzels, Polish pretzels, tiramisu, apple, cheese, or caramel strudel, croissants, cookies, brownies, cheesecake). Recently, it has introduced salads, sandwiches and soups, so customers can spend the entire lunch break inside the pastry-restaurant.

Since the beginning of the twentieth century, Turkish pastry shops have been a constant success, especially in the southern and south-eastern regions of Romania. Recently, such pastries have also opened in the western region of the country. The baclava, the cataif and the sarailia have always been preferred by a large number of Romanians.

At present, some bakeries and pastry shops in Romania (Boromir, Baneasa, Dobrogea, Vel Pitar, Pambac, Bunexim) export traditional products and specialties (biscuits, sweet rolls, cookies, pretzels, salty pastries, sweet bread) to the European countries where there are stores with Romanian products and a large number of Romanians who have emigrated (especially France, Italy, Spain, the United Kingdom, but also the countries of the Scandinavian Peninsula). Customers are not only Romanians working abroad, but also foreigners who want to try new tastes.

\section{CURRENT TRENDS IN CONSUMPTION}

In what the bakery products are concerned, according to the „Study on the Bakery Products Market and the Market of Flour Products", for 2018, made by Rompan, the white, traditional loaf, still holds a big share of the total market of bakery products, but the increase in the assortment diversity with new tastes and flavours are key factors that can drive sales. Then come the black bread, whole graham, rye bread, multi-grain bread, sales of which register increases, especially in the urban areas, among women and young people, because the products are perceived as healthier, as having fewer calories and are recommended by doctors.

In the last decade there has been a tendency to decrease the amount of bread consumed in Romania: consumption has decreased from $9.2 \mathrm{~kg} /$ month per capita in 2008 to about $8 \mathrm{~kg} / \mathrm{month}$ per capita.

There are significant differences in consumer behaviour depending on social class or region. Thus, among the unemployed there is a marked increase in the consumption of bread, reaching even monthly quantities of $9 \mathrm{~kg} /$ person, by $16 \%$ more than in 2017. In the regions with a lower standard of living, such as Oltenia, Muntenia or the North-East Region (Moldova), an increase in the consumption of bakery and bread products was seen in 2018, as compared to the previous year. 
According to the GfK study, $82 \%$ of Romanians have bread daily, 7 percent less than in 2009 when this category of frequent consumers of bread was $89 \%$ (Gallup study). As the bread consumption gradually decreases, the pastry consumption increases. The pastry products are not basic products, but comfort products, they are usually consumed as a snack or as a dessert and are preferred by young consumers from the urban area.

Given the current concern for a healthy diet, the frequency of consumption of these products is slightly lower, with 1 in 4 respondents consuming them only once a week. Confectionery and pretzels are products consumed especially by the inhabitants of the big cities, being a consumption habit of the type „on the go". The most consumed types of confectionery products are the sweet bread and the fresh pastry (strudels, patisserie, pastries), by about $60 \%$ of consumers; $46 \%$ of consumers use to have cakes, sweet rolls and 39\% - sponge cake; muffins / madeleines and frozen pastry are the least consumed - 13\% and 7\% respectively. Even though it is in the last place, in the last ten years the frozen pastry has registered a constant growth.

Consumers take into account, at the time of purchase, the quality and aspect of the products, the price, the content of E's and preservatives and the type of flour.

\section{PASTRY SHOPS AT THE BEGINNING OF THE $21^{\mathrm{ST}}$ CENTURY - CHARACTERISTICS AND DEVELOPMENT OPPORTUNITIES}

In a desire to permanently evolve and reinvent themselves, investors in the confectionery and confectionery field are concerned about:

- creating strong brands and promoting them through new communication channels (Internet - websites and social media);

- accessing European funds;

- the possibility to expand by opening more patisserie in the franchise;

- permanent contact with market news, by participating in national exhibitions (for example the GastroPan exhibition in Arad which will hold its 12th edition in March 2020) and international exhibitions (Le Salon de la Pâtisserie - Paris, SIGEP - international exhibition of ice cream, confectionery artisan bakery - Rimini, Expo Sweet - Exhibition for the confectionery and confectionery sectors - Warsaw, Artoza - International exhibition for the bakery and confectionery sectors - Athens, Modern Bakery Moscow - International exhibition for the bakery and confectionery industry - Moscow Bakepol - Specialized fair for the bakery and confectionery industry - Krakow, Südback - Exhibition for the bakery and confectionery industry - Stuttgart) or by participating in competitions for professionals (The World Trophy of Pastry Ice Cream and Chocolate - Milan).

- innovation (new products, special or specialized, new ingredients, with health benefits, new flavours, competitive prices, new technologies);

They try to achieve these goals by:

- focus on staff:

- sending the personnel to specialized courses, at home and abroad;

- reintroduction of apprenticeship under the guidance of pastry masters and confectioners (returning to the tradition of the beginning of the 20th century);

- focus on product:

- the orientation towards the traditional Romanian confectionery, reinvented, the old recipes adapted to the aesthetics and modern taste (for example „coliva” cone); 
- bringing to the attention of the Romanian customers some traditional products from other countries with which Romania has affinities: France (croissant, macaroons, madeleines, millefeuille / a thousand leaves, éclairs, small fruit tarts, artisan chocolate), Italy (canollo), Germany (kremschnitt, linzer);

- proposing traditional products of the national minorities, the Hungarian and German gastronomic culture having a strong influence especially in Transylvania (e.g. kürtőskalács, hájas, Beigli, Bretzeln, Strudel);

- creation of high-quality products for the business environment (e.g. fresh pastry specialties + coffee „to go", daily delivery of some pastry specialties to offices, creation of product packages for corporate events - parties, coffee breaks, conferences, personalized gift baskets for partners on the occasion of the holidays);

- focus on aesthetics:

- publishing on social networks (especially Instagram) photos of new, beautiful and elegant products, thus acting on the subconscious and on the purchase behaviour;

- adopting the concept of creative pastry - the baker becomes a designer;

- focus on ingredients:

- the use of quality ingredients, even if the price of products increases, as consumers are becoming more sophisticated;

- creation of less sweet products, with less sugar, less butter or lard, with flour richer in fibre;

- replacement of the ,star ingredient”, the chocolate, with fruits;

- introduction of vegan and raw vegan products, products without dough, only from seeds and fruits;

- giving up artificial dyes;

- finding solutions to replace the ingredients that causes food allergies;

- focus on spaces and location:

- arrangement of mixed spaces (tea shop + pastry shop, cafe + pastry shop, bistro + pastry shop / confectionery), preferred by young consumers;

- focus on customer:

- customer loyalty (small businesses, which are easier to control, require smaller investments, a small number of staff, a limited number of products, but have loyal customers);

The bakery sector is currently threatened by:

- catering services (1 strudel or croissant costs 2.2 lei compared to 4.5 lei in bakeries),

- the ,menu of the day', offered by restaurants (12-14 lei),

- the preference of young consumers for fast food.

\section{CONCLUSION}

The year 1990 marked a change in the consumers' behaviour in Romania. They gave up the products that were recommended based on the concept of ,rational eating" imposed by the communist era (according to which the basic product was black bread) and, faced with a rich offer (due to the imports and to the national companies that diversified their production), they started to prefer white bread and pastry specialties. Although over time theories have emerged that white bread was not healthy, it still has the highest market share.

Gradually, the big producers of bread and bakery products began to manufacture confectionery and pastry specialties, distributed through their own network of stores. Since the specialties are more expensive, the profit obtained is bigger. According to the studies carried out periodically 
by the patronage, the market for bakery and pastry products is increasing year by year, the big players on the market setting up special production lines for both fresh and frozen pastries. If at first the basic production was bread, now the production focuses on pastry. Also, these big producers are concerned with the implementation of the food safety management system.

The market for bakery and pastry products has become extremely dynamic and competitive. Besides the big producers, small companies appeared, which developed, evolved and turned into successful brands.

The range of pastry specialties has expanded, being enriched with products from France, Italy, Germany, Turkey, Hungary. These were adapted to the Romanian tradition and tastes, being assimilated by the population, who no longer perceives them as borrowed.

The range of ingredients has also been diversified. Enhancers and low-quality ingredients have appeared on the market, allowing for reasonable prices to be set. At the opposite pole there are the high-class ingredients, with which specialties are produced, but which have a limited number of consumers, with higher incomes, in the urban area, concerned about the quality of the products and a healthy lifestyle.

The other social classes will increasingly focus on frozen products, the price of which is lower and which we can find in the big chains of supermarkets.

The artisan pastry shops will only survive on the market as a niche sector, with high quality products and located in strategic positions, with high business reputation, located in tourist areas and in the middle of the big cities, where there are potential customers with high purchasing power.

In our opinion, the chance of the artisan bakery to survive is to make the shift toward the restaurant. In the coming years, the pastry shop will become the place where one can have a high-quality coffee, a delicious sandwich, and even a cream soup, a concept favoured by the corporate customers and the young generation.

\section{REFERENCES}

Balmer, J.M.T., Greyser S. (2003), Revealing the Corporation: Perspectives on Identity, Image, Reputation, Corporate Branding and Corporate Level Marketing, Routledge, London.

Bucci, L. (2019) « Pâtisserie: on vous dit tout sur les tendances du dessert », Dernières nouvelles d'Alsace, 19.06.2019, [Online], Available: https://www.dna.fr/actualite/2019/06/19/patisserie-on-vous-dit-tout-sur-les-tendances-du-dessert

Calvel, R. (1990) Le goût du Pain, Éditions Jerome Villette.

Cătoiu, I., Oancea, O., Pandelică, A. (2011) „Cercetări de marketing privind evaluarea decalajelor de percepţie asupra siguranţei alimentare existente între industria şi piaţa produselor de panificaţie din Romania" (Marketing research on evaluation of the perception gap focused on the food security between bakers industry and market in Romania), Revista de Marketing Online (Journal of Online Marketing), vol. 4 nr. 3, pp. 3-21.

Chiţu, M., Voiculescu (2013), „Românii, printre campionii Europei la consumul de pâine. Cât de sănătoasă este ,„pâinea noastră cea de toate zilele”. Reacţia nutriţioniştilor”, Gândul, 4.08.2013, [Online], Available : https://www.gandul.info/stiri/romanii-prin- 
tre-campionii-europei-la-consumul-de-paine-cat-de-sanatoasa-este-painea-noastra-cea-de-toate-zilele-reactia-nutritionistilor-11187721

Develey, A. (2017) «Éclair, macaron... L'histoire secrète de nos pâtisseries », Le Figaro, 23.03.2017, [Online], Available: https://www.lefigaro.fr/langue-francaise/expressions-francaises/2017/03/23/37003-20170323ARTFIG00013-eclair-macaron-1-histoire-secrete-de-nos-patisseries.php

Kolbay, G., 2018, ANPC a luat în vizor produsele de panificaţie congelate. Producătorii atrag atenţia: Ce riscăm dacă nu ştim exact ce conţin, [Online], Available: http://www.ziare. $\mathrm{com} /$ social/consumatori/anpc-a-luat-in-vizor-produsele-de-panificatie-congelate-producatorii-atrag-atentia-miza-e-sanatatea-romanilor-1506789.

Lindstrom, M. (2011) Buyology, Publica, Bucureşti.

Lindstrom, M. (2013) Brand Washed. Trucuri prin care companiile ne manipulează minţile şi ne conving să cumpărăm, Publica, Bucureşti.

Maior, D., Studiu de piaţă privind produsele de panificaţie (2), [Online], Available: http://www. rompan.ro/uploaded_files/file/Articol\%20aparut\%20in\%20Revista $\% 20$ Brutarul $\% 20$ iulie\%202010.pdf.

Pélissier, D. (2015) "Les organisations ont-elles ont une identité numérique? », Présence numérique des organisations, [Online], Available : http://presnumorg.hypotheses.org/34.

Popescu, M. (2008) « Site-ul web: Între modalitate de comunicare și instrument strategic de marketing ", Revista de marketing Online, vol. 2, nr. 1, pp. 39-45.

Porumb, A.T. (2016) « Mise en thème de l'identité organisationnelle: le cas du site web », Analele Universităţii din Oradea (Seria Ştiinte Economice), tom XXV, Vol. II, pp. 149-157.

Săseanu, A.S., Petrescu, R.M., Voica, D. (2009), The bakery industry - a favourable environment for the Romanian entrepreneurs", Analele Universităţii din Oradea (Seria Ştiinte Economice), tom XVIII, Vol. II, pp. 201-207.

Teodorescu, F., Toma, M., Pistol, M., 2019, „Tradiție și modernitate - condimentele în panificație”, Brutarul, 4.11.2019, [Online], Available https://brutarul.ro/traditie-si-modernitate-condimentele-in-panificatie/.

Van der Spuy, A. (2018) "Food as a Marker of Identity in My Beautiful Death by Eben Venter", Athens Journal of Philology, Volume 5, Issue 1, pp. 7-18.

\section{Internet sources:}

www.anamob.ro

www.artaalba.ro

www.brutarul.ro

https://www.castelanne.com/blog/evolution-patisserie/

https://www.didatticagenzialighieri.it/storia-della-pasticceria/

http://www.eattheglobe.com/story/the-history-of-french-pastry-and-confectionery-1100

http://www.patiseria-leon.ro/istoria-patiseriei.html

https://www.gfk.com/ro/

https://theculturetrip.com/europe/romania/articles/the-most-delicious-romanian-desserts/

https://www.forbes.ro/record-patiserii-ies-pe-piata-cu-5-milioane-de-bucati-de-pasca-si-75milioane-de-cozonaci-80957 